\title{
НАРОДНИ ЈЕЗИК У ДРАМАМА ЈОАКИМА ВУЈИЋА - ЛИНГВОКУЛТУРОЛОШКИ КОНЦЕПТ УВОЪЕЬА ФРАЗЕОЛОГИЗАМА У ДРАМСКИ ТЕКСТ
}

\begin{abstract}
Синтаксички, структурно-семантички и прагматски аспект употребе народног језика у предвуковској, славеносрпској епохи на корпусу Вујићевих драма били су предмет реферата на прошлогодишњем састанку слависта. У овом раду ћемо анализирати фразеологизме, устаљене изразе и колокацијске спојеве ексцерпиране из драме Слепи миш - најпре као структурно-семантичке репрезенте народног језика, а затим и као део специфичне Вујићеве поетике, у којој се осликавају његови специфични животни и филозофски ставови.

Кључне речи: славеносрпски језик, народни језик, пословице и паремиолошки изрази, устаљени изрази и колокације, фразеолошки изрази, ауторски фразеологизми.
\end{abstract}

1. На прошлогодишњем НССУВД говорили смо о елементима разговорног језика у Вујићевом делу. ${ }^{1}$ Како је једна од подтема овогодишњег скупа предвуковски и вуковски период у српском језику и књи ж е в н о с т и, дело Јоакима Вујића поново се чини као поуздан избор и извор. Иако се за име Јоакима Вујића готово колокацијски везује апозицијска етикета отац српског театра, треба нагласити да управо разнотипност, односно функционална раслојеност његовог стваралачког опуса чини овај избор оправданим. Наиме, не само да је као оснивач позоришта у Срба писао, или чешће, заправо, преводио и прилагођавао на српски (народни) језик велики број драма различите тематике, Вујић је иза себе оставио и путописе, дневничка дела, збирке поезије, различите уџбенике и приручнике, аутобиографију, те се као такав његов литерарни опус чини веома погодним за анализу језика славеносрпске, предвуковске епохе.

\footnotetext{
*t.matic@yahoo.com

${ }^{1}$ Целокупно дело Јоакима Вујића, његова језичка, конкретно синтаксичка (структурна), али и стилистичка и прагматска анализа предмет су нашег ширег научног интересовања.
} 
Драмски текст представља динамичан језички варијетет у ком су доминантне особине народног и народског језика у далеко већој мери присутне него у било ком другом функционалностилском регистру. Раније смо истакли да „експресивни изрази, често и изрази из тзв. нижег регистра (вулгаризми, клетве и псовке), затим колокације, паремије и фразеолошки изрази (у ширем смислу) представљају неке од заједничких експликација разговорног функционалног стила и драмског регистра као дела књижевно-уметничког функционалног стила" (Матић 2020: 138).

Јоаким Вујић је иза себе оставио значајан број драма, комедија, посрбљених једночинки, али и историјских и поучних драмских текстова. Писао их је готово све време свог стваралачког трајања (1805-1837), изводио их са својом путујућом трупом на импровизованим позорницама, у кафанама, али и у свом театру у Крагујевцу, режирао их па врло често и глумио у њима. Нису све Вујићеве драме штампане за његова живота, нису све ни штампане - неке су сачуване само у рукопису. Нажалост, нису све ни сачуване - неке су изгореле у шестоаприлском бомбардовању, а за неке постоје само подаци у Вујићевој аутобиографији на немачком језику из 1826. године.

2. Грађу за овај рад ексцерпирали смо из драме Слепьй мышъь, објављене 1809. године, Та весела игра у едномъ дбйствію, како је Вујић одређује у поднаслову, у великој мери представља посрбљени превод драме Die Fledermaus Карла Фридриха Ханслера из 1802. године.

Како би се боље разумели примери који ће бити анализирани, дајемо кратак синопсис драме: Главни лик је расипни капетан Божа Мирић, јунак из француског рата који се смртно плаши слепих мишева, осиромашен и задужен, те принуђен да се ожени наводно веома богатом, старијом госпођом Макреном Љутарош. У рату против дворских слепих мишева помаже му ратни друг и инвалид Тривун (Трифун), сада у служби у његовом двору, и разумни комшија Драгутин, коме капетан дугује новац. С друге старне, супруга обећава вечни рат због кукавичког понашања током прве брачне ноћи, за шта му се касније свети ослобађајући уплетеног слепог миша из његове косе и одсецајући највећи њен део. Љубица, капетанова кћи, неудата, и богати барон Паја, представљају секундарни сиромашно-богати пар, чија се веза, пак, завршава срећним исходом. Обрт у перцецији слепих мишева почиње када један од њих обори свећу на капетанову облигацију према Драгутину, и запали је, те он опрости дуг капетану. Други пут слепи мишеви помажу капетану када богати барон Паја бранећи част капетанове кћерке која је (иначе, лаж) бежећи од слепог миша остала сама у мраку са њим, запроси њену руку, те се капетан и на тај начин додатно финасијски консолидује. Трећи пут - сада већ тражећи слепог миша којег би хранио и неговао - капетан налази сандук са благом у делу дворишта где се по причи коју уводи Миша, стари тобџија, виђао Господаръ Луичіферъ на козиіима ногама. На крају - слепи миш се уплиће у косу Макрени, која пада са мердевина, на које се попела да би, прерушена у вукодлака, уплашила капетана, и гине.

3. Поделили смо је у две, односно три структурно-семантичке и лингвокултуролошке целине: пословице, односно различити паремиолошки изрази, 
те фразеолошки изрази - кодификовани с једне, те модификовани, Вујићеви ауторски фразеологизми, с друге стране

3.1. Пре него што их представимо, даћемо два интересантна разматрања која се тичу уводних страница драме. Прво ћемо се осврнути на цитат са поткорице драме који гласи:

Aspide quid pejus? Tygris: quid Tygride? Daemon. Daemone quid? Mulier. Quid Muliere? Nihil -

Што е горе оть Аспіде? Тvгръ ; што оть Тvгра? Демонъ. Оть Демона што? Жена. Што оть жене? Ништа - (СМ: 2)

На први поглед, иако прилично искључив и груб, мизогин(ски), цитат се може уклопити у наведени синопсис. Читаоци драме то свакако нису могли знати па се поставља питање ауторске мотивације за цитирањем на овом месту у драми, при чему латински оригинал пружа утисак дубинске мудрости и убедљивости. Међутим, широј лингвокултуролошкој анализи, те прецизнијој контекстуализацији овога необичног цитата вратићемо се на самом крају рада. У оригиналном Ханслеровом тексту овај део не постоји.

Друго разматрање односи се на прву следећу страну у тексту драме, а то је попис лица (протагониста драме). Наиме, два главна лика су Божа Миричъ, Мађарскій Немешъ и Капетанъ у Франиузскомъ рату и Макрена Лютарошка, нбгова жена одъ юче. Лако је уочљива мотивисаност ових антропонима. Капетан је неко ко се, дакле, помирио са Богом, пронашао Бога или сл. Касније ћемо видети да то врло лако може имати и своју секундарну мотивацију, којом би се могао представити шири концепт овог Вујићевог дела. Његова жена (од јуче) је Макрена (од грчког makros - велики) Љутарош, дакле неко ко је велика прзница, велика љутица, ко се веома често љути. Презимена доносе опет следећу, дериватолошку интепретацију: капетаново презиме се завршава аутентичним српским посесивним суфиксом - $u \hbar$, док презиме његове жене садржи суфикс -арош типичан за перцепцију мађарских презимена (хунгаризама уопште) у српском језику, додатно пак посрбљен крајњим српским суфиксом -ка, као сигналом да се Макрена већ удавала. Већ на основу пописа лица Вујић, дакле, наговештава карактеризацију ликова драме и тиме се на одређени начин наслања на необични цитат о жени с почетка драме. Оваква мотивација антропонима у Ханслеровом оригиналу не постоји. ${ }^{2}$

Можда би било згодно осврнути се и на начин на који Вујић додатно карактерише своје ликове у самом попису лица драме. Наиме, Божа Мирић је капетан и (мађарски) немеш. Лексикографске дефиниције речи немеш су следеће:

Немеш м (мађ). nemes) заст. и покр. племић, припадник племићког сталежа. (РСАНУ 15: 154-155)

\footnotetext{
${ }^{2}$ Анализу ономастикона оригинала и потврду да не постоји слична мотивација добили смо од колеге Бранислава Ивановића, са катедре за германистику, који се бави историјском фразеологијом немачког језика, на чему му захваљујемо.
} 
Немеш м 1. 'ситни угарски племић' 2. прен. а. 'надмен, охол човек који се понаша заповеднички; умишљени земљорадник, сељак који се понаша господски' б. 'лењ човек, онај који живи на туђ рачун'. (РСГВ 2005: 169-170)

У тексту драме видећемо да је треће (2б) значење из РСГВ прецизан опис Вујићевог главног лика. Овај поступак постоји у немачком оригиналу; тако да можемо закључити да су неки поступци језичке мотивације (имена или карактера) ликова оригинални, ауторски, а неки преузети заједно са самим текстом оригинала.

3.2. Прву групу класификованих израза чине пословице и паремиолошки изрази. Пошто смо их на одређен начин већ приказали у претходном раду, овде ћемо само навести ексцерпиране примере, те дати неке додатне коментаре, највише како бисмо дали потпуни увид у Вујићев принцип коришћења народног језика кроз употребу надреченичних, кондензованих конструкција какве јесу и пословице и фразеологизми, у ужем и у ширем смислу.

Вы знате ону пословицу⿱: Една луда, начини десет другый. (СМ: 7)

Едног Ђавола у кући имати и нестерпиме Кредиторе - чини и споля (и) изъ нутра pamъ. (CM: 13)

Ноћь никомъ нїе прїятель. (СМ: 22)

Стерпьнїе е добаръ Кредиторъ, али хрђавъ платаиъ... (СМ: 31)

Двадесеть година више живити, учисе вышие памети. (СМ: 35)

Зашто 4 добра речъ гвоздена врата отвора. (CM: 45)

Зашто самь у момъ веку чуо, да разуманъ мора попустити будали. (CM: 44)

Раније смо истакли да „не можемо са сигурношћу тврдити да се сви забележени примери могу сврстати у фонд српских народних пословица, али им се паремијски карактер не може оспорити. Неке од њих можемо наћи у фонду народних пословица које је Вук забележио (добра реч гвоздена врата отвара), за неке видимо да сам Вујић (односно Тривун) сигнализира да су пословице, а за све можемо рећи да имају пословичку структуру и призвук априорне мудрости” (Матић 2020: 144). Регистар пословица које је Вук Караџић забележио и објавио 1836, а који ми знамо из Просветиног издања Вукових сабраних дела, свакако није апсолутни регистар наших народних пословица, нарочито не свих варијаната појединачних пословица, али ми га након двеста година узимамо као образац, као нормирани фонд српских народних пословица.

3.3. Најзначајнију, структурно и семантички најзахтевнију за анализу, тиме најаутентичнију за разумевање драмског текста, чини корпус устаљених израза и колокација, те кодификованих, речничких/записаних фразеологизама с једне стране и, модификованих, ауторских фразеологизама, чије значење одогонета Вујићеву поетику и шире, с друге стране.

3.3.1. Прву групу чине уобичајени, мање или више прозрачни, фразеолошки и устаљени изрази, чврсто укорењени у нашем културном коду, би-

\footnotetext{
3 Занимљиво је нагласити веома рану употребу, 1809. година, самог термина йословице коју како видимо Вујић користи у једној од реплика.

${ }^{4}$ У језику представника славеносрпске епохе зашто се веома често - готово доследно користи уместо сложеног узрочног везника зато што.
} 
вајући тако репрезенти концептуланог континуитета на српском језичком простору.

Црна штета, да она како дБвственна Господична на онай светъ отлази. (CM: 58)

Капетанъ одъ стра оста укоченъ како годъ дирекъ. (СМ: 11)

Честно вовЬренну супругу оставля разаговарати се съ ветромъ. (СМ: 19)

Една гадна стара девойчура, дебела као четворка... (СМ: 9)

Пакъ пружи две дебеле ножурине како годъ два тулума на поль. (CМ: 11)

Немой ихъ преко воль трошити, Заштъ ћу се у гробу преврнути, Али мыслимъ да си човекъ правый, Ербо ћешь имати разум здравылй! $!^{5}$ Яша Миричь. (СМ: 55)

Мой Благодьтель каже, да ће се у гробу преврнути, ако новцы на каквогъ распикућу дойћу. (СМ: 57)

Па и моја покойна мамица у гробу мора се за ово оскорбити, и одъ еда валяати - яо жалости и туге моје довека! (СМ: 16)

Држъ (се) добро и не уступай натрагъ, зашто ћешь показати леђа. (CM: 14)

Она је наймань до 50. година натоварила на своя леђа. (СМ: 8-9)

(CM: 20)

Я самь вами садъ на две ноге Слепогъ Мыша, Вашу драгу супругу съ врата скинуо.

Издвојени фразеологизми су у Вујићевом језику искоришћени како би се појачала експресивност драмских ликова, у њихове реплике унела динамичност, често да би се постигао ефекат комичности и, примарно, текст приближио гледаоцима. Различитих су структруних типова, поредбени фразеологизми, глаголско-именичке фразеолошке синтагме и реченични фразеологизми, што сведочи о заиста богатом и разноврсном корпусу такве грађе у Вујићевом тексту.

Већина примера представња лексикализоване, прозрачне фразеолошке изразе, које често срећемо и у савременом језику, а који су забележени у фразеолошким или енциклопедијским речницима српског или српскохрватског језика (П1-8).

П1 је подударан забележеноме у фразеолошком речнику, оtići pf. (рос́i pf., preseliti (se) i sl.) na onaj (na drugi) svijet umrijeti (МАТ: 668); у П2 примећујемо лексичку варијантност поредбене допуне, па уместо лексеме пањ имамо експресивнију дирек, sjediti ipf. (stajati ipf.) ukočen kao panj sjediti/ stajati nepomično/tupo/bez razumijevanja i osjećanja (MAT: 448). П3 представља морфосинтаксичку варијанту лексикализованог, govoriti ipf. reći pf. (lajati i dr.) u vjetar govoriti uzalud (МАТ: 744), па уместо ППК y + акузатив имамо $c+$ инструментал. Ипак, и код једне и код друге варијанте израза (или код оба фразеолошка израза) може се као заједничка извући архисема узалудности.

П4 и П5 представљају поредбене фразеологизме с негативном конотацијом чије значење није апсолутно прозрачно, односно не може се одмах видети веза поредбене речи са имплицитним негативним контекстом као допуном поређене речи, придевског, дебела. Међутим, дефиниције одредни-

\footnotetext{
${ }^{5}$ У овом изразу може се евентуално анализирати и присуство риме, која би се могла објаснити (ауторовом) интенцијом да се изразу поред неупитне древности припише и етикета априорне мудрости.
} 
ца у референтним речницима, четворка ж 3. буре од четири акова. Вук. $P j^{6}$ (PMC VI: 867) и tulum, m mijeh, mješina za prenošenje ili čuvanje različnih stvari potrebnih za piće ili jelo (RJAZU XVIII: 904), откривају да је у питању обличка (негативна) метафоризација.

П6-8 представљају пример вишеструке употребе једног фразеологизма или варијанте истог фразеолошког израза, okretati se pf. (prevrnuti se pf. i sl.) u grobu začuditi se, zaprepastiti se (zbog neobične/nepredvidive pojave, neobičnog događaja). (MAT: 172). П6 и П7 представљају контекстуално један израз поновљен (прочитан) два пута у драмском тексту и лексички одговарају лексикализованом фразеологизму. У П8 Вујић користи синонимну глаголску лексему ваљати се (са узрочним локализмом од једа), где се употребом имперфективног (донекле и итеративног) глагола израз интензификује јер се очекивана непријатна радња сада понавља. Двострука интензификација постигнута је употребом изразито експресивног глагола, оскорбити, оскорбим свр. 1. в. оскрбити ${ }^{2}$. (РСАНУ 18: 344) - оскрбити ${ }^{2}$, оскрбим свр. заст. 1. растужити, ожалостити. (РСАНУ 18: 345). ${ }^{7}$ Ипак, може се констатовати да je, иако појачана, емоција емитована глаголским делом фразеолошког израза истосмерна. Међутим, ако се детаљније размотри структурно-семантичка реализација П6 и П7, може се констатовати донекле онеобичена форма израза. Устаљена семантичка форма израза би подразумевала да учесници у дијалогу субјектом (темом) реферишу на треће лице, неприсутну, покојну особу (групу особа). У П6 директно, а у П7 у форми индиректног говора, реплика се приписује управо покојнику. Буквализацијом фразеолошког израза Вујић појачава комичност ситуације, али и дидактичност поруке о штедљивости (богатству) као пожељном концепту.

У П9-11 имамо сличне примере креирња ауторских фразеологизама. П9 представња буквализацију израза, pokazati pf. komu leđa otići/udaljiti se od nekoga (MAT: 308), док се, слично тако, у П11 експликацијиом бриге из фразеологизма, skinuti pf. komu brigu s vrata osloboditi koga brige/čega neprijatnoga (MAT: 43), постиже додатни ефекат комичног, а протагонисти драме се на сликовит начин детаљније профилишу. П10 је један од ефектнијих ауторских фразеолошких израза Јоаким Вујића - представља укрштање два лексикализована израза, imati ipf. mnogo (šezdeset, sedamdeset i sl.) godina na grbači (na leđima) biti star, ostarjeti. (MAT: 159), и, tovariti ipf. natovariti pf. što na čija leđa bacati/prebaciti brigu/odgovornost na koga. (MAT: 309). ${ }^{8}$ Наравно, Вујић на овај начин карикира своје ликове, учвршћује њихове специфичности (како Тривуна, који реплику изговара, тако и Макрену, на коју се она односи), те сугеришући да је Госпођа Макрена одговорна за терет

\footnotetext{
${ }^{6}$ Упућивање на Вуков рјечник ('dolium capax quatuor amphorarum’) у дефинициији из РМС можемо узети као доказ актуелности фразеолошког израза у датом временском контексту.

${ }^{7}$ Уколико претпоставимо да у овом примеру Вујић циљано супроставља славеносрпски

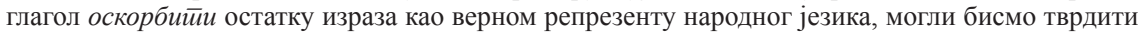
да је то још један модел интензификације (фразеолошког) израза.

${ }^{8}$ Svaliti (navaliti, natovariti i sl.) na čija leđa što - opteretiti koga čime, svaliti svoju brigu ili svoj posao na drugoga (ХФР: 284).
} 
својих година, да их је сама себи натоварила на леђа, комедију ситуације подиже на виши ниво. ${ }^{9}$

3.3.2. Као посебну групу примера, заправо као извесну међугрупу која би повезивала кодификоване, лексикализоване и ауторске фразеолошке изразе (3.3.1.) и Вујићеве лингвокултуролошки изразито специфичне ауторске изразе (3.3.3.), издвојили смо примере чије нам је значење на прво читање било апсолутно неприступачно, уз евидентно страно порекло, те донекле контекстуално наслутиву мотивацију.

Сакрлотинайнъ - Госп: Капетанъ! Я бы желїо, да бы она подъ моїомъ Коммандомъ была - (CM: 21)

Есу ли овде гди годъ близу пустаїе? - Сакрлотъ! Ево ме готовогъ! (СМ: 37)

Сакрлотхїнайнъ! Мы смо благо нашли. (СМ: 54)

Штіль Канайлїо сакрментска - таки испредъ мои очїю! - за што ћу ти главу полупати. (CM: 42)

У прва три примера назначили смо лексему - израз чије нам значење није било познато, а чија се експресивност могла наслути као и њено, на основу творбеног модела дуже верзије (али и језика оригинала драме), готово извесно немачко порекло. Краћи облик би опет могао упућивати на неки други језик давалац. Дефиниција глаголске именице сапрлотирање из речника JАЗУ даје објашњење како значења тако и порекла нашег израза:

SAPRLOTIRAŃE, $n$. nem. verb. od glag. saprlotirati (t. j. govoriti saprlot), komu nema potvrde u građi ovoga rječnika. Glagol je načinen od od vulgarne ńem. riječi (uzvika) sapperlot, a ta od sackerlot (sto mu muka!), u kojoj je pokvarena franc. riječ sacré (prokleti! do đavola!). Samo u jednom primjeru: Sve mu saprlotirańa iz usta lete. Obradović basne 246. (PJA3Y XIV: 633).

Додатна и веома корисна информација коју налазимо у цитираној дефиницији јесте да једина потврда у речничкој грађи јесте из Достејевих басни, што нас наводи на закључак да је овај израз са значењем опште (скоро десемантизоване) псовке позајмљеница типична за саму славеносрпску епоху. ${ }^{10}$

Како бисмо анализирали назначени израз из П4, издвојили смо дефиниције појединачних лексема из адекватних речника:

still 3. kao int.: !, seid ((i. schweight) ! tišina!, mir!, ćut’, ćutite!; (Ристић/Кангрга 1963: 441)

сакрамент м. лат. цркв. света тајна, обред који по хришћанском схватању даје неку милост и посвећење. [сакраментски који се односи на сакраменте] (РСЈ 2018: 1128)

\footnotetext{
${ }^{9}$ Овакав модел смо раније установили у дискурсу савременог драмског писца Александра Поповића, нарочито у драмама Развојни йуй Боре шнајдера и Мрављи метееж, нпр. Сабио сам им рогове у врећу или За данас нам је ӣуна кайа ирних вест̄и (в. Матић 2016). Било би интересантно испитати да ли се овакав модел креирања ауторских фразеологизаама може дефинисати као карактеристика језика српске драме.

${ }^{10}$ Милован Сучевић у раду Језик у делима Досииеја Обрадовића о популарно писаним местима у његовим делима наводи и најфреквентније (одомаћене) германизме наводи: „грунть, найфайнїе, сапрлотираня, солдатъ, унтеръофициръ, талъ, фуртъ, щрапацъ и т. д.“ (Сучевић 1914: 6-7)
} 
канајлија м и ж (фр. canaille; нем. Canaille) заст. изрод, олош, йробисвеӣ, битианга. - Хај, канајлијо! одазва се Дон Кихоте, нема за ме бикова, који што вреде (Поп. Ђ. 8, 211) (PCAHУ IX: 183).

канаља ж и м покр. неваљалац, нийков, хуља. - Попе Марко, мораш видити из овога, да је Унија једна превара, и кад Гуверанову канаљу Дон Тому пушта чинити проминивати у годину дана четири закона да и теби неима пута једну бесиду рећи (МСД 1934, 78) (PCAHУ IX: 186).

канајља (1789) - олош, руља. Мучи, канайліо (3О, 60); каналіа - das Lumpengefinde (НР, 76); нећу да гледамъ вышше ту Канайлію; проклета Канайліо (љ3, 26, 35); мы морамо те канайліе побити (ИК, 76). < ит. canaglia (Михајловић 1972: 235).

У дефиницији најнепрозирније лексеме из цитираног израза, коју видимо у Грађи за речник страних речи у предвуковском периоду В. Михајловића могу се издвојити две ствари: прво, порекло речи, које се разликује од оног на које се упућује у првој дефиницији из РСАНУ - Вујић је добро говорио и италијански; и друго, управо су из Вујићеве драме Любовная зависть чрезъ едне uїпеле из 1805. године наведена два цитата, контекстуално и морфосинтаксички најближа примеру ексцерпираном из драме Слепьй мышъ. У прилог овој подудадрности иду и године објављивања двеју драма, 1805. и 1809. година, па можемо закључити да је на почетку Вујићевог стваралаштва ова лексема била инхерентни део његовог ауторског и фразеолошког лексикона.

3.3.3. Последња група примера уочена је тек након анализе првобитно ексцерпиране грађе, дакле не током самог процеса читања, иако би њена лексичко-семантичка специфичност можда указивала на супротно. Одговор на ову перцептивну нелогичност се крије вероватно у намери аутора да ти примери и не буду на прво читање посматрани као једна целина. Дубља лексичко-семантичка и прагматска анализа потврдиће ове наше ставове. Но, треба нагласити да се разумевање ових ауторских израза често може посматрати само у контексту целога текста, а не као изоловани језички модел.

Да е зла и пакостна, како годъ Баба Луиіфер пакленогъ. (СМ: 9)

Пакъ садъ се разлютила какогодъ Аспіда - цело ютро данась по двору мрмляме, псоваме, какогодъ каква бесна кучка. (СМ: 13)

Тко ће га одъ вражке бабе ослободити? Завежляй е еданъ путъ завезатъ, когъ ни Антїхрїсть веће раздрешити не може. (CM: 14)

Дотрча кокогодъ фурія паклена изъ међу ны (ЈВ - дидаскалија) (СМ: 19)

У оваковима случайма жене биваю, какогодъ Фуріе паклене и Aсnіде едовите (СМ: 20)

Да се тамо веће виђао Господаръ Луцїферъ на козїима ногама - частный га кресть nотрео - буди Богъ съ нама и анђели Божїи. (СМ: 46)

(CM: 46)

Да бы га истый Господаръ Луцїферь у пакао са собомъ одвео, да тамо шливе суши!

Мы ћемо се начинити како годъ вукодлащьы (СМ: 46)

Дакле, Господаръ Слепьй Мышь опеть и овай е посао добро ко концу привео. (CM: 51) Богъ да іой души прости - на врби їой кости - на тополи ноге! ${ }^{11}$ (СМ: 59)

\footnotetext{
${ }^{11}$ Овај израз нећемо посебно анализирати у тексту јер би то додатно оптеретило обим рада. Међутим, треба нагласити да израз подсећа на дечије песмице, игре речима, брзалице, а које су најчешће заправо десемантизоване варијанте старих народних бајања и обредних песама. Постојање јасне риме ( $\bar{p} о с \bar{u} u-\kappa о с \bar{u} u)$, те увођење митског (култног, вилинског) дрвећа иде у прилог нашој претпоставци да израз представља басму (мистиичне речи које се изговарају йри бајању, РСАНУ I: 319) или, пак, њен одређени део, које је Вујић циљано преузео.
} 
И мене може быти опетъ одъ женске аждае и Луизїрера пакленогъ освободио! (CМ: 60)

Одъ данась быћь Слепый Мышь подъ моимъ покровителствомъ, нитко да се не усуди ни наймань додирнути га (СМ: 60)

Овај невелики број примера структурно, а више лексичко-семантички се издваја од осталих ексцерпираних и анализираних делова драмског текста. Значење није прозрачно, напротив. Део су ширег лингвокултуролошког концепта заснованог на фразеологији и фолклористици, хришћанском и предхришћанском наслеђу, мањим или већим делом и на европском мистицизму XVIII и XIX века.

Издвојени примери као заједничку архисему имају инвоцирање Луцифера, односно Антихриста, ђавола, претпоставимо концепта пакла и паклених бића генерално. Неки од њих представљају вернакуларизоване или препознатљиве концепте (Антихрист, аспиде, змије и фурије), док се код преосталих (Луцифер) не може са сигурношћу рећи да се могу идентификовати као део тадашњег религијско-митског концепта у српском народу.

Наиме, у српској фразеологији не постоји концепт Луцифера, већ само концепт антибога, антихриста, ђавола, сатане, сатанаила. У оригиналу драме само се на једном месту помиње Луцифер (Luzifer) - дакле, донекле можемо искључити могућност да аутор то чини под утицајем изворног текста. Добрим делом на то упућује и Вујићев животопис, о чему сведоче речи Божидара Ковачека из предговора Нолитовом издању изабраних драма Јоакима Вујића:

Као што се нико није освртао ни на индикације да се Вујићеве идеје често поистовећују са слободнозидарским, чак и у питањима религије. Земунски свештеници га туже митрополиту Стратимировићу за безбожништво. Масон је, то знамо, био његов узор Доситеј. По свему судећи, Вујић и не би морао бити онакав пуки прагматиста каквим га видимо. Ко зна чиме су све били условљени његови животни и идејни компромиси који се тако радо истичу као карактеристика његове личности (Ковачек 1987: 9-10).

У постулатима европског мистицизма из периода 18. и 19. века, на којима је заснован и концепт масонског, слободнозидарског (па и алхемичарског, илуминаторског) погледа на свет - централно место заузима стварање новог света, раскидање са актуелним догмама, религијама, царствима, стварање новог Бога - Луцифера. Луцифера, носиоца светла, звезде данице, предводника палих анђела, предводника новог света, пакла који није место таме, већ светлости, светлости црног сунца. Стварање света чији је основни принцип и циљ богатство, материјално или духовно, зависно од специфичности датог покрета.

Даље, Луцифер се доследно помиње као господар (Господар, Баба), он се указује на месту где ће се на крају, захваљујући, опет, слепим мишевима, пронаћи благо, које је, како смо рекли, основни циљ луциферијанаца. У поглављу Ђаво у народним културама Алфонсо ди Нола каже да је „ђаво у читавој европској традицији чувар и откривач скривеног блага” (2008: 387), те „да се налази и близу скривених блага, као њихов љубоморни чувар, уједно као дух подземног блага" (Исто: 384), а да је уобичајено приказан с рогови- 
ма, репом, рачвастим козјим копитама, наглашавајући да су „ниже културе наследиле ону најстарију традиционалну форму демонске слике: полуљудска или полуживотињска структура која долази из касне античке митологије фауна, сатира, Пана, уопштено становника шуме и самоће ко га j e хришћанска полемика претворила у демона" (Ди Нола 2008: 375) [истакао Т. М.]. Видимо, дакле, да Вујић на суптилан, али веома прецизан начин разрађује жељене социолошко-фолклористичке концепте, не оптерећујући тиме ток радње, насупрот, дајући јој тиме на динамичности.

Као што се перцепција слепих мишева (Слепог миша) мења како се радња ближи крају, претпостављамо да Вујић на сличан начин жели представити могућност перцепције Антибога - Луцифера, нигде то експлицитно не наводећи, наравно. Међутим, честа могућност супституције двају концепата или двеју експликација сличног (или истог) концепта, може нас навести на овакав закључак. Синтаксички то потврђују примери 1,6 . и 9 - у прва два Господаръ, односно Баба атрибутивно одређују именицу Луйіферъ, а у трећем примеру (који је већ из дела драме када су расплет, али и прекретница/обрт у схватању слепих мишева почели) исти атрибутив је уз именичку синтагму 'слепи миш' - Господаръ је Слепьий Мылшъ.

Д. Мршевић-Радовић у књизи Фразеологија и национална култура, у делу у ком говори о концепту сиромашних духом на моделу ииш и голии каже да су „у европској демонологији и езотерији бројне текстуалне и ликовне представе ђавола с атрибутима слепог миша" и упућује на илустрацију „Demon šišmiš jaše na zmaju” из Rječnika simbola (Мршевић Радовић 2014: 221). Ако се, ношени овом идејом, сада вратимо на перцепцију комплетне драмске радње, видећемо да Јоаким Вујић веома вешто скрива, али и указује на овакве или сличне концепте. Његово двојако приказивање Слепог миша, као штеточине и опасности на почетку, а избавитеља, свемогућег и свеприсутног на крају, иде томе у прилог.

Госпођа Макрена је отета под окриљем мрака, завијена у машкару, што је један од фолклористичких модела приказивања слепог миша; слепи мишеви пресудно истичу на исход радње, свемогући су, страх од њих на крају прелази у љубав, захвалност, обожаваност. У П12 видимо да се аутор поставља као његов заштитиник, покровитељ (поштовалац), а завршном поруком (последњим пасусом) драме истиче безрезервно дивљење његовим моћима, наспрам немоћи других:

У овомъ двору живяше ньгда еданъ Слепый Мышъ, кой у ньговомъ животу вишше добра чиняше, него какавъ обожаемый човекъ; кой хїляду срећный учинити могаше, а никогъ нїе учинїо. (СМ: 61)

На крају, вратићемо се на мизогини цитат са полеђине насловне стране драме.

Aspide quid pejus? Tygris: quid Tygride? Daemon. Daemone quid? Mulier. Quid Muliere? Nihil -

Што е горе отъ Аспіде? Түгръ ; што отъ Тvгра? Демонъ. Отъ Демона што? Жена. Што оть жене? Ништа - (СМ: 2) 
Ако се узме да је ова весела игра у једном дејсиивију драма о злој жени - рекло би се да је с разлогом ту. Међутим, тај цитат на латинском језику пронашли смо у књизи „MIRABILIA MUNDI”, с поднасловом. Kurtzes und curioses Gemisch und Gemasch oder Beschreibung Sehr vieler Welt-Wunder из 1729. године. У слободном преводу: Чуда света: кратки и интересантни описи много светских чуда и чудних ствари. Међутим, превод остатка насловне, прве стране ${ }^{12}$ открива суштински садржај књиге: у њему се, парафразирамо, каже да је то књига у којој се могу наћи невероватне саге и битке, магични градови вредни посете и невероватни цареви, краљеви, муслимански и папски (католички, хришћански) поглавари у свету њихове лажне религије или верске доктрине, баш као и приче о много звезда на небу и седам планета, о џиновским китовима, новој земљи (новом свету) и великим острвима, и на крају много поучних прича (Carmina) о лошим/злим женама и другим стварима. Још једном се, дакле, разоткривају вешто скривени, а довољно наговештени (тадашњи) Вујићеви филозофски и животни назори инспирисани мистицизмом Европе, односно слободнозидарским, масонским идејама и литературом његовог времена.

4. ЗАКљУЧАК. Језик драма Јоакима Вујића је изузетно богат и веома поуздан корпус за анализу народног језика предвуковске и вуковске епохе у нашој књижевности. Вујић се њиме служи како би драмску радњу приближио гледаоцима, текст драме учинио разумљивијим вешто користећи изразе из свакодневног живота, а опет управо тим изразима ненаметљиво и прецизно градећи своје специфичне драмске ликове. Употреба надреченичних кондензованих конструкција, пословица и различитих паремиолошких израза с једне, те устаљених израза, колокација и фразеологизама с друге стране у Вујићевом опусу представља доминантан и врло ефектан начин увођења народног и народског језика у књижевни текст. Користи их у изворној, лексикализованој форми, али их и прерађује, модификује, укршта, најчешће с циљем додатне карактеризације протагониста драме, појачавајући тиме комичност ситуације. Такође, поједине ауторске фразеолошке изразе Вујић користи како би на суптилан, али веома прецизан начин наговестио жељене социолошко-фолклористичке концепте, не оптерећујући тиме ток радње, насупрот, дајући јој тиме на динамичности.

\section{ИЗВОР}

Вујић 1809: Іоакимъ Вуичъ, Слепьй мылшь, Въ Будинь Градь: Писмены Кралевскаго Всеучилища Венгерскаго [61 стр.] [CM]. ${ }^{13}$

\footnotetext{
${ }^{12}$ Помоћ за превод дугујемо двема полазницама 49. скупа слависта из Келна, Немачке.

13 (http://digital.bms.rs/ebiblioteka/pageFlip/reader/index.php?type=publications\&id=1299\&m=2 \#page/5/mode/1up)
} 


\section{ЛИТЕРАТУРА}

Албијанић 1982: Александар Албијанић, Од рационализма ка романтизму: Кратак осврт на позоришни језик Јоакима Вујића, Научни састанак слависта у Вукове дане, 12, 43-53.

Албијанић 1986: Александар Албијанић, Језик нештампаних драма Јоакима Вујића, Зборник Матице српске за филологију и лингвистику, XXIX/1, $113-125$.

Албијанић 2010: Александар Албијанић, Прилози о српском предвуковском књижевном језику, Нови Сад: Матица српска; Београд: ЗУНС; Вукова задужбина.

Главуртић 1978: Miro Glavurtić, Satana, Uvod u demonologiju, Beograd: Miro Glavurtić (Grafičko preduzeće „Prosveta”).

Даничић 1871: Gjuro Daničić (ur.), Poslovice, Zagreb: U knjižarnici fr. Župana (Albrechta i Fiedlera).

Ди Нола 2008: Alfonso di Nola, Đavo, Beograd: Clio.

Ђорђевић 1898: Пера П. Ђорђевић, О реду речи у српском језику, (приступна академска беседа), Глас Српске краљевске академије, LIII, 167-231.

Караџић 1964: Вук Караџић, Српски рјечник 1818, Сабрана дела, II, Београд: Просвета.

Караџић 1965: Вук Караџић, Српске народне пословище, Сабрана дела, IX, Београд: Просвета.

Ковачевић ${ }^{4}$ 2015: Милош Ковачевић, Стилистика и граматика стилских фигура, Београд: Јасен.

Ковачек и др. 1988: Божидар Ковачек, Петар Марјановић, Душан Михаиловић, Душан Рњак, O театарском делу Јоакима Вујића, Нови Сад: Матица српска, Одељење за сценске уметности и музику.

Матешић 1982: Josip Matešić, Frazeološki rječnik hrvatskoga ili srpskog jezika, Zagreb: Školska knjiga [MAT].

Матић 2016: Томислав Матић, Прагматска анализа индивидуалних фразеолошких израза у драмама Александра Поповића, Научни састанак слависта у Вукове дане, 45/1, 407-418.

Матић 2020: Томислав Матић, Елементи разговорног стила као репрезенти народног језика у драмама Јоакима Вујића, Научни састанак слависта у Вукове дане, 49/1, 137-148.

Милановић 2014: Александар Милановић, Језик Јована Суботића, Београд: Филолошки факултет.

Михајловић 1972: Велимир Михајловић, Грађа за речник страних речи у предвуковском периоду, I том (А-Љ), Нови Сад: Институт за лингвистику.

Младеновић 1989: Александар Младеновић, Славеносрпски језик, Нови Сад: Књижевна заједница Новог Сада.

Мршевић Радовић 22014: Драгана Мршевић-Радовић, Фразеологија и нациионална култура, Београд: Друштво за српски језик и књижевност. 
Пипер и др. 2005: Предраг Пипер, Ивана Антонић, Владислава Ружић, Срето Танасић, Људмила Поповић, Бранко Тошовић, Синтакса савременог српског језика, Проста реченица, Београд: Институт за српски језик САНУ, Београдска књига; Нови Сад: Матица српска.

Ристић/Кангрга 1963: Svetomir Ristić, Jovan Kangrga, Enciklopedijski nemačko-srpskohrvatski rečnik, II, Beograd: Prosveta.

PJA3У 1880-1976: Rječnik hrvatskoga ili srpskoga jezika Jugoslavenske akademije znanosti i umjetnosti, I-XXIII, Zagreb: JAZU.

PМC 1967-1976: Речник српскохрватскога књижевног језика, I-VI, Нови Сад: Матица српска.

PC 2003: Rječnik simbola: mitovi, sni, običaji, geste, oblici, likovi, boje, brojevi (red. J. Chevalier, A. Gheerbrant), Banja Luka: Romanov.

РСАНУ 1959-2017: Речник српскохрватског књижевног и народног језика, књига I-XX, Београд: Институт за српски језик САНУ.

РСГВ 2005: Речник српских говора Војводине, 5: М-Њ, Нови Сад: Матица српска.

PCJ 2018: Речник српскога језика, Нови Сад: Матица српска.

Симић 1991: Радоје Симић, О нашем књижевном језику, Никшић: НИП „Универзитетска ријеч”.

Сучевић 1914: Милован Сучевић, Језик у делима Доситеја Обрадовића, Извештај Српске православне велике гимназије ср. карловачке за школску 1913./14, У Срем. Карловцима: Српска манастирска штампарија.

Тошовић 2002: Бранко Тошовић, Функиионални стилови, Београд: Београдска књига.

Ујес 1985: Алојз Ујес, Позоришно стварање и трајање Јоакима Вујића 1805-1985, Крагујевац: Одбор за обележавање 150-годишњице првог српског позоришта.

Ујес 1988: Алојз Ујес, Позоришно стваралаштво Јоакима Вујића, (поводом 175-годишњице прве позоришне представе у Срба 24. августа 1813), Београд: САНУ.

XФP 2014: Antica Menac, Željka Fink Arsovski, Radomir Venturin, Hrvatski frazeološki rječnik, Zagreb: Naklada Ljevak.

Tomislav Matić

VERNACULAR IN JOAKIM VUJIC'S PLAYS - THE LINGUOCULTOROLOGICAL CONCEPT OF INTRODUCING PHRASEOLOGISMS IN THE DRAMATIC TEXT

\section{Summary}

The language of Joakim Vujić's plays is an exceptionally rich and highly reliable corpus for the analysis of the vernacular of the pre-Vuk and Vuk's epoch in our literature. In Vujić's opus, the use of suprasentential condensed constructions, proverbs and different paremiological expressions on the one hand, and formulaic expressions, collocations and phraseologisms on the other hand, represents a dominant and highly effective way of introducing the vernacular in the literary text. He uses them 
in the original, lexicalised form, while at the same time reworking, modifying and combining them, most often with the aim of further characterisation of the plays' protagonists, amplifying thereby the comicality of the situation. Vujić also uses some authorial phraseological expressions to adumbrate the desired sociological-folkloric concepts in a subtle, but highly precise way, without burdening the course of action, but, on the contrary, adding to its dynamics.

Key words: Slavonic-Serbian language, vernacular, proverbs and paremiological expressions, formulaic expressions and collocations, phraseological expressions, authorial phraseologisms. 